\title{
The Importance of the Assessment of Quality of Life in Glaucoma Patients
}

\begin{abstract}
Glaucoma is a chronic, progressive eye disorder that can lead to visual impairment and blindness. The projection of glaucoma prevalence in the world suggests that in 2020, 79,6 million of people will have glaucoma, 11,2 million of them will be bilaterally blind. The chronic disease, such as glaucoma, affects the different roles of a patient in everyday life and his/her well-being. Quality of Life (QoL) helps to define the inability of performing specific task that is most important to patient. Patients' perspective on their visual impairment and well-being are essential in the planning of management of glaucoma. The assessment of QoL should be standard procedure in the management of glaucoma patients. In clinical practice it should represent a gold standard in the care of chronic patients and a proof of fulfilling the patients' rights. The assessments of QoL should serve as a tool for good clinical practice, for respecting the patients' rights, and respect for the value of human life in general.
\end{abstract}

Keywords: Quality of life, glaucoma, patients' perspective, rights of the patients.

\section{Introduction}

Glaucoma is a chronic, progressive eye disorder that can lead to visual impairment and blindness $(1,2)$. In the early stage glaucoma is often asymptomatic, therefore undiagnosed chronic disease with irreversible consequences on the vision, physical, psychical and social life of the patients. It is assumed that only half of glaucoma patients in developed countries are aware of their disease (3), in comparison

\footnotetext{
*Department of Ophthalmology, Faculty of Medicine, University of Rijeka.

** Department of Social Sciences and Medical Humanities, Faculty of Medicine, University of Rijeka.

Correspondence address: Goran Pelčić, Department of Ophthalmology, Faculty of Medicine, University of Rijeka, Braće Branchetta 20, 51000 Rijeka, Croatia. E-mail: goran.pelcic@medri.uniri.hr.
} 
to $90 \%$ of unaware glaucoma patients in the developing countries. Glaucoma is important public health issue of $21^{\text {st }}$ century $(4,5,6,7)$. The projection of glaucoma prevalence in the world suggests that in 2020, 79,6 million of people will have glaucoma and 11,2 million of them will be bilaterally blind $(6,8)$. As Bourne $(2,9,6)$ suggested, many papers started with the sentence that "Glaucoma is the second leading cause of vision loss in the world" that actually could represent awareness of researchers worldwide regarding the seriousness of glaucoma's consequences. The ophthalmologists worldwide are focused more on how to maintain the intraocular pressure (IOP) within the normal values or how to preserve the visual function of their patients, while the patients are focused on their ability to fulfill everyday's tasks and roles in everyday's lives (family, business or social roles). The chronic disease, such glaucoma is, effects the different roles of patients and well-being of the patients too. Perspectives of ophthalmologist and perspectives of glaucoma patients regarding the different important issues in management of glaucoma sometimes do not coincide (10). Ophthalmologists should be aware of the importance of well-being for the glaucoma patients, and should estimate it through their work. Measuring the quality of life (QoL) related to the health and vision can assess the well-being of patients. One of the most important aims of the glaucoma management is preservation of QoL of glaucoma patients.

\section{Glaucoma}

Glaucoma is a chronic neurodegenerative disorder that could lead to irreversible changes of retinal ganglion cells and loss of optic nerve cells (7). If not treated properly and timely, it could cause severe vision impairment and blindness. Generally, glaucoma mostly affects people over 40 years of age. Visual impairments are the highest in older population (11) with an effect on visual function and general well-being. The demographic characteristics in the world suggest that along with the population ageing there is a higher prevalence of glaucoma $(1,12,13,14)$. On the other hand, the worldwide trend is an increasing age of working active population. It is assumed that there will be a great number of working active population suffering from glaucoma and its' consequences on working ability and everyday functioning. The review of literature suggests that advanced glaucoma degrades the patient's general health, Quality of life (QoL), and vision related to quality of life $(2,10,15)$. The chronic disease has negative impact on patients' physical, emotional and social aspects of life $(11,16)$. 


\section{Quality of life}

One of the most important aims of the glaucoma management is preservation of glaucoma patients' QoL $(16,17,18,19,20,21)$. The goal of the ophthalmologist is prevention of the loss of health related quality of life (HRQOL).

QoL could be defined as person's own estimation of physical, psychological or social well-being $(17,19)$. It is important to assess the multidimensional characteristics of QoL such as physical parameters (sign of illness and therapy), functional (ability to move and mobility), social (interpersonal contact and relationships) or psychological (mental health and stability) $(22,23,24)$.

The instruments used to assess QoL identify presence or absence or severity and frequency of different types of symptoms (16). But they are not useful for the identification of the priority of particular symptoms, which mostly disturbs the patient. The ability to work, drive the car, do the sports, to be active in social life are indirect signs of successful glaucoma therapy. These elements contribute to preservation of good QoL.

QoL is not a constant value, it differs in one patient over time (19) or depending on the situation (25). QoL of two persons suffering from the same diagnosis is different. Various factors can contribute to QoL, such as culture, social environment, or the patients' expectations in life.

The researcher's goal is to choose an instrument to measure QoL (26). Mainly, those instruments are self-reported or interview administered questionnaires (19). Health related questionnaires, which are used in glaucoma patients for assessing QoL, could be divided in general health questionnaires and disease related questionnaires $(17,19,22)$.

In this paper we will put an emphasis on disease related questionnaires or visionspecific QoL questionnaires in glaucoma patients.

\section{Instruments for assessing the QoL in glaucoma patients}

The Activities of Daily Scale (ADVS) originally was addressed to cataract patients. ADVS is made of 22 questions divided in 5 subgroups (near vision, distant vision, glare disability, daytime driving and night driving) (19).

The Visual Function Index (VF-14) originally was designed to assess functional impairment in patients with cataract (19). 
The Visual Activities Questionnaire (VAQ) is made of 33 questions divided in 10 subgroups. The aim of VAQ is to assess the difficulties in everyday's visual problem in older glaucoma patients (19).

The Impact of Vision Impairment (IVI) consists of 32 questions regarding the impact of visual impairment on everyday life experience (19).

The National Eye Institute Visual Function Questionnaire (NEI-VFQ) consists of 25 questions regarding the impact of different ocular problems on everyday vision functioning $(17,19)$.

The Glaucoma Symptoms Scale (GSS) is constructed to assess 10 symptoms that glaucoma patients experience (visual and non-visual symptoms) (19).

The Viswanathan Questionnaire is constructed of 10 questions with yes or no responses regarding the ability to find a lost object, or climb up the stairs, or bump into the objects (19).

The Glaucoma Quality of Life (GQL-15) is composed of 15 questions for the purpose of assessing the stage of functional disability $(17,19)$.

Glaucoma Symptom Identifier (GSI) is constructed to identify various glaucoma symptoms with their impact on QoL (17).

Independent Mobility Questionnaire (IMQ) is constructed for measurement of patients' ability for independent mobility (17).

Comparison of Ophthalmic Medications for Tolerability (COMTOL) is constructed for use in clinical trials in order to compare the side effects of medication therapy and impact on QoL (17).

Treatment Satisfaction Survey-Intraocular Pressure (TSS-IOP) is designed for assessment of patient's satisfaction regarding the different aspects of topical antiglaucoma medication.

In general, patient-reported outcomes can be divided in three categories: those which address functional status regarding the vision; those which assess QoL in general, and the third one which detect other issues connected to the disease and treatment (17). Until today there are no ideal questionnaires for assessing QoL in glaucoma patients.

\section{Glaucoma Patients' perspectives on the QoL}

Difficulty and inability to perform daily activities often bring the patient to the ophthalmologist's office before the patient actually knew that he has glaucoma. 
Irreversible changes of optic nerve axon and retinal ganglion cells result in inability to perform many visual demanding tasks (27), such as difficulties while reading, writing, dressing, traveling in glaucoma patients (24). Functional loss, anxiety due to diagnosis, the costs of treatment, or inconveniences might also have negative impact on QoL (28). Patients usually report bumping into the things, difficulties in climbing stairs, etc.

QoL helps to define the inability of performing specific task that is most important to patient. This is very important moment in planning the management of glaucoma. Because of that, the assessing of QoL in clinical practice is important for allocation of limited resources and for therapy planning of particular patient (16).

Even a moderate visual impairment leads to deterioration of patient's QoL $(2,29)$ regardless of the primary ocular diagnosis. Moderate visual impairment can lead to deterioration of visual impairment, and can have a negative impact on emotional well, increased functional disabilities. These findings were collected from the patients' perspectives, because of their negative impact on patients' well-being. They suggest that even the patients with moderate visual impairment should undergo further evaluation of their vision health status. Without exploring the patients' perspective regarding the moderate visual impairment, ophthalmologist might postpone further evaluation of vision that could lead to more serious deterioration of visual impairment with the consequences on emotional status, family, business, or social functioning.

\section{Why QoL instruments should be assessed in clinical practice regarding glaucoma patients?}

The assessment of QoL in glaucoma patients, regardless of the type of QoL questionnaires, has multiple benefits on glaucoma patients' well-being. It reminds ophthalmologist that his/her perspective on success of glaucoma treatment might differ from patients' perspectives. It reminds patients of glaucoma consequences on everyday tasks that he/her is not able to perform anymore. It recalls that adherence to the lifelong therapy is important for patient functioning and fulfilling life tasks in family, business or social environment.

There are wide possibilities available to assess the QoL in glaucoma patients $(7,19)$ but it seems that these possibilities are mostly reserved for the researches' purposes and not for the clinical practice. On the other hand, the perception of patients suggests the necessity of including the assessment of QoL in daily work of ophthalmologists. As Waisbourd suggests, every ophthalmologist should ask him/herself how he/she can preserve or even improve the health and well-being of their patients (7). The ophthalmologists' interest should not focus only on the value of intraocular pressure 
or on visual field loss, it should also focus on the possibilities of patients to perform different daily activities. The patients' reports regarding difficulties in daily activities could have an impact on clinical decision making and antiglaucoma therapy planning. If these elements are not taken into account, the right of the patients to proper care could be disturbed.

On the other hand, assessing QoL (health related or vision related) instruments in undiagnosed glaucoma patients could serve as a diagnostic tool. McKean-Cowdin et all (2) performed study in which they assessed health related QoL instrument among the participants who were not aware of their glaucoma diagnosis at that time. Among the 6357 participants, 291 were identified with open angle glaucoma (OAG), 75\% of them were diagnosed glaucoma for the first time. Those diagnosed glaucoma for the first time had modest levels of vision loss, but lower health related QoL. It could be assumed that assessing HRQoL instruments in settings such as general medicine office or in general ophthalmological office might serve as a screening tool for glaucoma in the patients who have lower HRQoL.

\section{Bioethical approach regarding QoL}

If QoL is determined by well-being, which is a more subjective factor, then it is difficult to accurately define QoL (30). There are several values that are gained by assessing QoL:

a. The progression of illness and success of therapy could be measured

b. Analyzing the database of the previously obtained QoL data, physician can choose the best appropriate therapy for the present patient

c. The databases can provide the information regarding side effects of specific treatment

d. Assessment of the cost effectiveness of certain therapy

The assessment of QoL has a dangerous side, as is the case where somebody's subjective perception of QoL is low, this could lead to value QoL as the quality of human person with consequent discussion of whether this person should receive medical treatment or is it worth living (30).

Addressing the participants of the Study Congress of the Pontifical Academy for Life "Quality of life and ethics of health“, Pope John Paul II said that theme „... is of the greatest ethical and cultural importance for both developed and developing societies" (31). He emphasizes the danger of understanding the QoL through the health economics, consumerism, physical beauty and pleasure, while forgetting the essence of QoL, such as interpersonal, spiritual, and religious existence. 


\section{The utilitarian perspectives}

Pragmatic utilitarian perspectives evaluate QoL as minimizing the pain and the economic costs (32). Utilitarian perspectives are based on the ethic of consequentiality. There are human lives worth living and those which are not worth living. There are different measurements, such as minimum intellectual capacity self-awareness, self-control, orientation in time and spaces, capacity to relate to others, interest for others, capacity to communicate. Other measure can be hedonistic perspectives.

The utility theory, developed in 1940 and implemented in health care by the 1970s, associate QoL with health care. Utility analysis enabled objective evaluation of QoL in health care, especially associated with visual field loss $(10,33,34)$. A utility value of 1.0 correlates with good health, while a value of 0.0 correlates with death. The higher the utility value, the better the QoL is. Regarding the ophthalmology, utility values decrease in correlation with visual loss (10).

As we represent, there are possibilities of different perspectives of patients and ophthalmologists regarding the glaucoma patients' well-being. An appropriate approach to glaucoma patient necessary includes patient's perception of his/her wellbeing and subjective self-reported measures together with the clinical measures, and performed based measures (7). A holistic, complete approach to a patient, in this case to a glaucoma patient, needs time. Because of the shortage of time, health care policies, unclear regulation, or lack of the regulation regarding implementation of the health care, the glaucoma patient often does not receive holistic approach from his/her ophthalmologist. In the bioethical sense, the plan for assessment of glaucoma patients should include all above mentioned elements. Many authors agree that consideration of patients' perspectives and preferences should be gold standard in establishing the impairment caused by a health state and eventual improvement in QoL $(10,35)$.

The health care decisions often have to be individualized. Two patients might have the similar score in Qol measurements but with different perceptions of one's own well-being or the patients' and physicians' perspectives on the same results could have opposite perception of patients' health status and well-being. As well, the choices between possible outcomes may be viewed differently by different patients (35) or physicians.

\section{Conclusion}

Awareness of the importance of QoL and its' assessment in glaucoma patients goes beyond the research and statistics. The assessment of QoL of glaucoma patients should 
be the standard procedure in clinical practice, the base for future therapy planning. The QoL assessment is a way to incorporate patients' perspectives on their wellbeing into the future therapy planning. It is the guarantee to incorporate patients' rights in everyday practice. To prevent a global pandemic of glaucoma patients, the assessment of health and vision related QoL should be considered as a diagnostic tool for glaucoma patients. The QoL assessment is generally of great value to patients but could be interpreted from an unethical perspective and unethical reasons.

\section{References}

1. Severn P, Fraser S, Finch T, May C. Which quality of life score is best for glaucoma patients and why? BMC Ophthalmol. 2008 Jan 23;8:2.

2. McKean-Cowdin R, Wang Y, Wu J, Azen SP, Varma R; Los Angeles Latino Eye Study Group. Impact of visual field loss on health-related quality of life in glaucoma: the Los Angeles Latino Eye Study. Ophthalmology. 2008 Jun;115(6):941-948.e1.

3. Sommer A, Tielsch JM, Katz J, Quigley HA, Gottsch JD, Javitt J, Singh K. Relationship between intraocular pressure and primary open-angle gluacoma among white and black Americans. Arch Ophthalmol 1991See comment in PubMed Commons below;109(8):1090-5.

4. Tham YC, Li X, Wong TY, Quigley HA, Aung T, Cheng CY. Global prevalence of glaucoma and projections of glaucoma burden through 2040: a systematic review and meta-analysis. Ophthalmology 2014; 121(11):2081-90.

5. Pelčić G. Glaucoma as a public helath problem. Medicina fluminensis 2011; 47(3):299-307.

6. Buys Y, Goldberg I, Lambrou GN, Ritch R. World Glaucoma Day, 6 March 2008: tackling the glaucoma pandemic. Acta Ophtalmol 2008;86:124-5.

7. Waisbourd M, Parker S, Ekici F i sur. A prospective, longitudinal, observational cohort study examining how glaucoma affects quality of life an visually-related function over 4 years: design and methodology. BMC Ophthalmology 2015;15:91. doi: 10.1186/s12886-015-0088-x.

8. Quigley HA, Broman AT. The number of people with glaucoma worldwide in 2010 and $2020 . \mathrm{Br}$ J Ophthalmol 2006;90:262-7.

9. Bourne RRA. Worldwide glaucoma through the looking glass. Br J Ophthalmol 2006;90:253-4.

10. Brown GC, Brown MM, Sharma S, Brown HC. Patient perceptions of quality-of-life associated with bilateral visual loss. Int Ophthalmol 1998;22(5):307-12.

11. Esteban JJ, Martínez MS, Navalón PG, Serrano OP, Patiño JR, Purón ME, Martínez-Vizcaíno V. Visual impairment and quality of life: gender differences in the elderly in Cuenca, Spain. Qual Life Res. 2008 Feb;17(1):37-45.

12. Keenan TD, Wotton CJ, Goldacre MJ. Recent trends in the rate of trabeculectomy in England. Eye (Lond) 2011;25(9):1243-5.

13. Census 2001. Population by age and sex by Settlements, Consensus 2001. 2001. http://www.dzs.hr/ Hrv/censuses/Census2001/Popis/H01_01_01/H01_01_01.html. Assessed 15 Febr 2016.

14. Croatian Bureau of Statistics. Statistical Year Book of the Republic of Croatia 2012. 104-126. Year 44. Coden SLRHED. 2012. http://www.dzs.hr/Hrv_Eng/ljetopis/2012/sljh2012.pdf. Assessed 2 March 2016. 
15. Gutierrez P, Wilson MR, Johnson C, Gordon M, Cioffi GA, Ritch R, Sherwood M, Meng K, Mangione CM. Influence of glaucomatous visual field loss on health-related quality of life. See comment in PubMed Commons belowArch Ophthalmol. 1997 Jun;115(6):777-84.

16. Aspinall PA, Johnson ZK, Azuara-Blanco A, Montarzino A, Brice R, Vickers A. Evaluation of quality of life and priorities of patients with glaucoma. Invest Ophthalmol Vis Sci 2008; 49(5):1907-15.

17. Quaranta L, Riva I, Gerardi C, Oddone F, Floriano I, Konstas AG.Quality of Life in Glaucoma: A Review of the Literature. Adv Ther. 2016 Jun;33(6):959-81.

18. van Gestel A, Webers CAB, Beckers HJM, van Dongen MCJM, Severens JL, Hendrikse F, Schouten JSAG. The relationship between visual field loss in glaucoma and health-related quality-of-life. Eye 2010; 24:1759-69.

19. Spratt A, Kotecha A, Viswanathan A. Quality of Life in Glaucoma. JOCGP 2008; 2(1):39-45.

20. Hirooka K, Sato S, Nitta E, Tsujikawa A. The Relationship Between Vision-related Quality of Life and Visual Function in Glaucoma Patients. J Glaucoma. 2016 Jun;25(6):505-9.

21. Nelson P, Aspinall P, Papasouliotis O, Worton B, O'Brien C. Quality of life in glaucoma and its relationship with visual function. J Glaucoma 2003;12(2):139-50.

22. Pelčić G, Glavina I, Jakab J. Assessment of Quolity of Life in Glaucoma Patients. Lijec Vjesn 2017;139(1-2):32-7.

23. Li Y, Crews JE, Elam-Evans LD i sur. Visual impairment and healthrelated quality of life among elderly adults with age-related eye diseases. Qual Life Res 201;20(6):845-52.

24. Friedman DS, Freeman E, Munoz B, Jampel HD, West SK. Glaucoma and mobility performance: the Salisbury Eye Evaluation Project. Ophthalmology. 2007 Dec;114(12):2232-7.

25. Guedes RA, Guedes VM, Freitas SM, Chaoubah A. Quality of life of glaucoma patients under medical therapy with different prostaglandins. Clin Ophthalmol 2012;6:1749-53.

26. Valderas JM, Alonso J, Prieto L, Espallargues M, Castells X. Content-based interpretation aids for health-related quality of life measures in clinical practice. An example for the visual function index (VF-14). Qual Life Res. 2004 Feb;13(1):35-44.

27. Skalicky SE, McAlinden C, Khatib T, Anthony LM, Sim SY, Martin KR, Goldberg I, McCluskey P. Activity Limitation in Glaucoma: Objective Assessment by the Cambridge Glaucoma Visual Function Test. Invest Ophthalmol Vis Sci. 2016 Nov 1;57(14):6158-6166.

28. Paletta Guedes RA, Paletta Guedes VM, Freitas SM, Chaoubah A. Does the type of treatment have an influence on utility values in a glaucoma population? Clin Ophthalmol. 2015 Sep 7;9:1645-50.

29. Finger RP, Fenwick E, Marella M, Dirani M, Holz FG, Chiang PP, Lamoureux EL. The impact of vision impairment on vision-specific quality of life in Germany. See comment in PubMed Commons belowInvest Ophthalmol Vis Sci 2011;52(6):3613-9.

30. Sgreccia E, Carrasco de Paola, editors. Qality of Life and Ethics of Health. Lelkens J. Quality of life in Cancer Patients with Unfavourable prgnosis. Proceedings of the 11th Assembly of the Pontifical Academy for life; 2005 Feb 21-23; Vatican City: Libreria Editrice Vaticana 2006. Available at: http://www.academiavita.org/_pdf/assemblies/11/quality_of_life_and_the_ethics_of_health.pdf. Assesed June 242017.

31. Sgreccia E, Carrasco de Paola, editors. Qality of Life and Ethics of Health. Pope John Paul II. Address to the President of the PontificalAcademy for life. Proceedings of the 11th Assembly of the Pontifical Academy for life; 2005 Feb 21-23; Vatican City: Libreria Editrice Vaticana 2006. Available at: http://www.academiavita.org/_pdf/assemblies/11/quality_of_life_and_the_ethics_of_health.pdf. Assessed June 242017. 
32. Sgreccia E, Carrasco de Paola, editors. Qality of Life and Ethics of Health. Barragán JL. Ten Year after „Evangelium Vitae“. The Quality of life. Proceedings of the 11th Assembly of the Pontifical Academy for life; 2005 Feb 21-23; Vatican City: Libreria Editrice Vaticana 2006. Available at: http://www. academiavita.org/_pdf/assemblies/11/quality_of_life_and_the_ethics_of_health.pdf. Assessed June 242017.

33. Brown GC, Sharma S, Brown MM, Kistler J. Utility values and age-related macular degeneration. Arch Ophthalmol. 2000;118(1):47-51.

34. Brown MM, Brown GC, Sharma S, Busbee B. Quality of life associated with visual loss: a time tradeoff utility analysis comparison with medical health states. Ophthalmology 2003;110(6):1076-81.

35. Kassirer JP. Incorporating patients' preferences into medical decisions. N Engl J Med. 1994 Jun 30;330(26):1895-6.

\section{Važnost ispitivanja kvalitete života kod pacijenata oboljelih od glaukoma}

\section{SAŽETAK}

Glaukom je kronična, progresivna očna bolest koja može dovesti do oštećenja vida i sljepoće. Projekcije prevalencije glaukoma u svijetu sugeriraju kako će 2020. godine 79,6 milijuna ljudi imati glaukom, dok će 11,2 milijuna biti obostrano slijepo. Kronična bolest, kao što je glaukom, utječe na različite životne uloge oboljelog i njegovu dobrobit. Određivanje kvalitete života (QoL) pomaže odrediti koje svakodnevne zadatke pacijent ne može izvršiti, a za njega su najvažniji. Pacijentova perspektiva na oštećenje vida i njegovu dobrobit esencijalni je element u planiranju liječenja. Ispitivanje kvalitete života trebalo bi biti standardni postupak u skrbi o pacijentu s glaukomom. Ispitivanje QoL-a u kliničkoj praksi trebalo bi predstavljati zlatni standard u skrbi o kroničnom pacijentu i poštovanju njegovih prava. Ispitivanje QoL-a trebalo bi služiti kao sredstvo dobre kliničke prakse i poštovanja prava pacijenata, kao i poštovanja ljudskog života općenito.

Ključne riječi: kvaliteta života, glaukom, perspektiva pacijenta, prava pacijenata. 